\title{
PEMBUATAN INTI STATOR MOTOR LISTRIK DENGAN MENGGUNAKAN PROSES MILLING PROFIL
}

\section{ELECTRIC MOTOR STATOR CORE MAKING USING PROFILE MILLING PROCESS}

\author{
Sony Harbintoro, Luky Krisnadi \\ Balai Besar Logam dan Mesin - Kementerian Perindustrian \\ Jalan Sangkuriang Nomor 12 Bandung 40135 \\ E-mail : sony-harbintoro@kemenperin.go.id
}

Diterima : 10-08-2020

Direvisi : 20-08-2020

Disetujui : 01-12-2020

\begin{abstract}
ABSTRAK
Inti stator motor listrik terbuat dari tumpukan lempengan pelat material electrical steel lamination, yang pada proses pembuatannya umumnya menggunakan metode stamping. Pada tulisan ini dijelaskan mengenai metode alternatif pembuatan inti stator motor listrik dengan menggunakan proses milling pada mesin CNC vertical machining center. Tahapan penelitian dilakukan dengan pembuatan desain inti stator, pembuatan alat bantu untuk mencekam tumpukan pelat electrical steel lamination, kemudian dilanjutkan dengan proses penentuan parameter pemesinan, proses milling profil di mesin CNC vertical machining center, dan melakukan analisa hasil eksperimen. Berdasarkan hasil penelitian, pembuatan inti stator yang terbuat dari pelat electrical steel lamination, dapat dilakukan dengan metode alternatif yaitu proses milling profil pada mesin CNC vertical machining center. Dibandingkan dengan proses stamping, proses pembuatan inti stator dengan proses milling profil pada mesin CNC vertical machining center mempunyai kelebihan yaitu perubahan desain produk dapat dilakukan dengan cepat tanpa harus mengubah dies dan punch. Proses pembuatan pelat inti stator dengan menggunakan CNC vertical machining center lebih sesuai digunakan pada tahap purwarupa sebelum dilanjutkan ke tahap produksi massal.
\end{abstract}

Kata kunci : electrical steel lamination, milling, stamping, stator

\begin{abstract}
The core of the electric motor stator is made of stacks of electrical steel lamination plates. In making of stator of the electric motor, it is generally used the stamping method. In this paper explained an alternative method of making a stator of the electric motor by using a milling process on a CNC verti cal machining center. The stages of the research were carried out by making the design of stator core, making of fixture to clamp the stacks of electric steel lamination plates, then proceed with the determination of machining parameters, the profile milling process in the CNC vertical machining center, and analyzing the experimental results. Based on the research results, the manufacture of stator of the electric motor made of electrical steel lamination plates can be done by an alternative method, namely the profile milling process in the CNC vertical machining center. Compared to the stamping process, the process of making a stator core with the profile milling process on a CNC vertical machining center machine has advantages, namely product design changes can be done quickly without having to change the dies and punch. The process of making stator core plates using CNC vertical machining center is more suitable for use in the prototype stage before going to the mass production stage.
\end{abstract}

Keywords : electrical steel lamination, milling, stamping, stator 


\section{PENDAHULUAN}

T nti besi atau biasa disebut stator merupakan bagian untuk dudukan/rumah gulungan kawat tembaga. Inti besi pada motor listrik berfungsi untuk menghantarkan dan mengarahkan fluks magnet ke setiap kumparan untuk memutarkan rotor. Inti besi terbuat dari tumpukan lempengan-lempengan material pelat electrical steel lamination. Konstruksinya terdiri atas tumpukan lempengan-lempengan dengan maksud agar dapat mengurangi panas yang berlebih yang dapat mengakibatkan fatigue dan degradasi pada inti besi (Silwal dan Sergeant, 2018).

Pelat electrical steel lamination merupakan material yang terbuat dari besi paduan yang dirancang untuk menghasilkan sifat magnetik yang spesifik. Pada produksi massal pembuatan inti besi motor listrik yang terbuat dari pelat electrical steel lamination, menggunakan proses stamping yang merupakan proses yang paling banyak diaplikasikan. Namun pada proses stamping terdapat beberapa kelemahan seperti dari segi biaya pembuatan dies \& punch yang mahal dan juga volume produksi harus banyak (masal). Oleh karenanya, proses ini sangat tidak menguntungkan pada pembuatan desain produk dengan volume sedikit (Zhang dan Spath, 2020). Pada proses stamping untuk pembuatan inti besi stator berbahan pelat electrical steel lamination dengan ketebalan pelat yang tipis yakni antara $0.27-0.50 \mathrm{~mm}(0.0106-0.012$ inch), maka diperlukan tingkat presisi tinggi dalam menentukan toleransi gap antara punch dan dies-nya. Biasanya celah pemotongan antar punch dan dies berkisar antara $2-5 \%$ dari ketebalan pelat yang di-stamping (Hubert et al., 2017). Semakin tipis pelat yang di-stamping maka celah pemotongan antar punch dan dies semakin sempit, hal ini berimplikasi terhadap proses pembuatan punch dan dies yang presisi, menyebabkan biaya pembuatannya menjadi tinggi. Untuk mencapai tingkat presisi yang tinggi digunakan proses gerinda (Harbintoro et al., 2020). Pada pembuatan dies \& punch yang akan digunakan untuk memotong pelat inti besi yang terbuat dari electrical steel lamination diperlukan material yang mempunyai sifat tidak mudah aus terhadap gesekan. Pada proses stamping diperlukan energi yang besar untuk memotong pelat electrical steel lamination sesuai kontur profil dies-nya.

Selain dengan proses stamping, pembuatan inti besi dapat juga menggunakan mesin laser cutting. Laser cutting dapat digunakan untuk memotong pelat tipis (Baumann dan Rauscher, 2019). Dengan menggunakan proses laser cutting, volume produk yang dibuat bisa sedikit namun penggunaan mesin laser cutting memerlukan biaya yang cukup mahal sehingga tidak kompetitif. Selain itu penggunaan mesin laser cutting memerlukan energi listrik yang besar.

Fenomena inilah yang menyebabkan perlunya metode pendekatan lain dalam pembuatan inti stator motor listrik. Metode alternatif dalam proses manufaktur bertujuan untuk mengurangi biaya manufaktur (Chinchwad et al., 2018). Eksperimental pembuatan inti stator dengan proses milling profil dilakukan dengan menggunakan mesin CNC vertical machining center. Proses milling adalah proses pemesinan datar, melengkung atau permukaan tidak beraturan (Gusev et al., 2017).

Pada proses milling di mesin CNC vertical machining center, cutting tools bergerak melalui benda kerja pada kecepatan putaran spindle, dalam putaran per menit (rpm), dan feed rate yang ditentukan dalam inch per menit (IPM), serta kedalaman pemotongan (depth of cut). Permasalahan yang sering dihadapi pada proses milling adalah menentukan kecepatan putaran cutting tools dan feed rate yang sesuai, dimana kedua parameter ini akan berpengaruh pada kekuatan potong dan waktu proses milling (Jin et al., 2017).

Parameter kecepatan dan feed rate bisa didapatkan berdasarkan pada bentuk dan warna chip, bunyi yang ditimbulkan pada saat pemotongan, dan pembacaan meter spindle load pada mesin. Sumber data terbaik untuk mendapatkan parameter kecepatan 
pemotongan, aplikasi, dan material tertentu yang dipotong adalah berdasarkan data sheet dari cutting tools. Sumber data untuk menentukan parameter kecepatan dan feed rate lainnya adalah berdasarkan data base pada perangkat lunak CAD/CAM yang saat ini telah menjadi semakin canggih dan dapat memberikan data pemotongan yang baik (Pontevedra et al., 2018).

Tujuan eksperimen perekayasaan ini yaitu melakukan pembuatan inti stator motor listrik yang terbuat dari pelat electrical steel lamination dengan menggunakan proses milling profil pada mesin CNC vertical machining center sebagai metode alternatif dalam proses manufakturnya. Pada penelitian ini, desain inti stator motor listrik yang digunakan sebagai eksperimen yaitu stator motor listrik BLDC 800 Watt, sebagai penggerak sepeda motor listrik.

Penggunaan metode pemesinan CNC milling profil pada pembuatan inti stator motor listrik berdasarkan pada metode subtractive rapid prototyping (SRP). Pada metode SRP dilakukan pembuatan prototip fungsional dalam jumlah yang sedikit Autodesk Inc., (2014). Prototip fungsional dibuat dari material yang struktur komponennya dapat diuji dan dirakit seperti halnya bagian dari komponen mesin. Metode SPR dapat mereflesikan desain manufaktur yang tepat sehingga dapat mengurangi biaya dan waktu disaat melakukan perubahan tahapan dari konsep desain menjadi produk.

\section{BAHAN DAN METODE Waktu dan Tempat}

Penelitian ini dilakukan pada bulan April - Desember 2019 melalui tahapan perancangan eksperimen, perancangan alat bantu, proses machining, pengumpulan data, dan analisa data, bertempat di workshop pemesinan Balai Besar Logam dan Mesin (BBLM/MIDC) Bandung.

\section{Bahan dan Alat}

Penelitian dilakukan dengan menggunakan material pelat electrical steel lamination sebagai benda kerja pada mesin CNC vertical machining center. Pelat electrical steel lamination merupakan material khusus yang terbuat dari silicon steel digunakan pada pembuatan inti stator. Spesifikasi pelat electrical steel lamination yang digunakan pada penelitian ini, ditunjukan pada Tabel 1 dan Mesin CNC vertical machining center yang digunakan pada penelitian ini dapat dilihat pada Tabel 2 berikut ini.

Tabel 1. Spesifikasi pelat baja silikon

\begin{tabular}{clcc}
\hline No & \multicolumn{3}{c}{ Data Teknis } \\
\hline 1 & Tipe & Electrical Steel & Non Oriented \\
\hline 2 & Ketebalan & 0.0106 & Inch \\
\hline 3 & Titik lebur & 1500 & ${ }^{\circ} \mathrm{C}$ \\
\hline 4 & Massa jenis & 7.65 & $\mathrm{~kg} / \mathrm{m} 3$ \\
\hline 5 & Resistivitas & $4.72 \times 10-7$ & $\Omega . \mathrm{M}$ \\
\hline
\end{tabular}

Tabel 2. Alat yang digunakan

\begin{tabular}{clcl}
\hline No & \multicolumn{4}{c}{ Data Teknis mesin CNC vertical machining center } \\
\hline 1 & Area kerja $X / Y / Z$ & $39.37 / 21.65 / 19.68$ & Inch \\
\hline 2 & Luas permukaan kerja & $43.3 \times 19.68$ & Inch \\
\hline 3 & Kecepatan putaran spindle & 10000 & rpm \\
\hline
\end{tabular}




\begin{tabular}{clcc}
4 & Kecepatan feedrate rapid $X / Y / Z$ & $1.417 / 1.417 / 1.181$ & IPM \\
\hline 5 & Feedrate $X / Y / Z$ & 945 & IPM \\
\hline
\end{tabular}

Cutting tools yang digunakan pada saat eksperimen proses machining untuk pembuatan pelat inti stator motor listrik :

Drill, diameter : 0.125 " dan 0.28 "

Flat End Mill (FEM), Diameter: 0.125 " dan 0.24 "

\section{Metodologi Penelitian}

Skema tahapan kegiatan ekperimen pembuatan inti stator dengan menggunakan proses milling profil pada mesin CNC vertical machining center, ditunjukan pada gambar berikut.

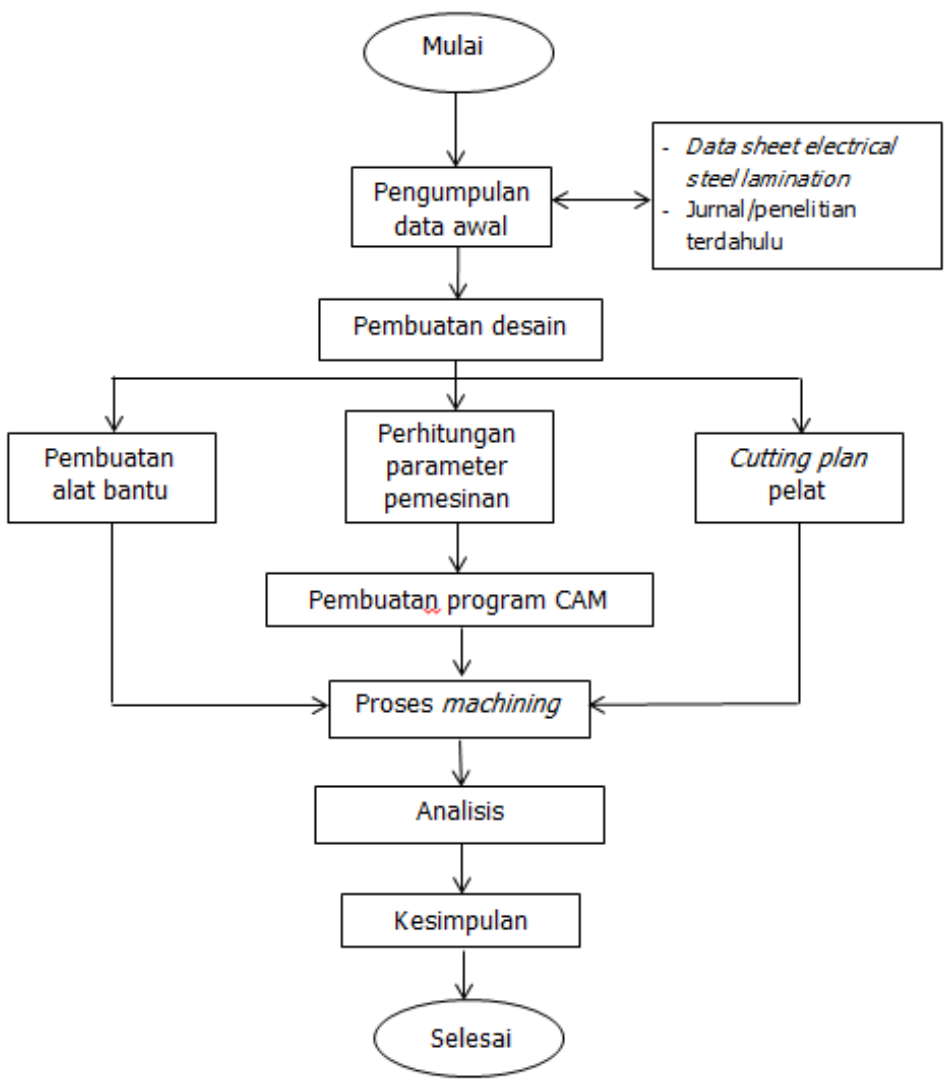

Gambar 1. Diagram alir kegiatan

Pengumpulan data awal dilakukan dari sumber data sheet pabrikan pembuat electrical steel lamination yang digunakan sebagai acuan untuk setting parameter pada proses di mesin CNC vertical machining center. Proses pembuatan desain merupakan salah satu tahapan pada persiapan penelitian. Dari gambar desain untuk inti stator motor listrik maka dapat diketahui kebutuhan cutting tools serta alat bantu yang akan digunakan pada proses penelitian. Pembuatan alat bantu diperlukan untuk mencekam tumpukan pelat electrical steel lamination pada meja mesin CNC vertical machining center. Proses setting parameter pada mesin diantaranya yaitu kecepatan putaran spindle, feedrate serta kedalaman pemotongan cutting tools pada benda kerja. Proses machining merupakan tahapan selanjutnya, dimana pada tahapan ini dilakukan proses milling pelat electrical steel lamination sesuai dengan desain yang yang telah dibuat. Pengumpulan data dilakukan pada saat proses machining untuk dilakukan analisa penelitian. 
Untuk pelaksanaan eksperimen pembuatan inti besi motor listrik dengan menggunakan proses milling pada mesin CNC vertical machining center, maka diperlukan desain geometri inti stator. Dengan desain inti stator ini diharapkan perilaku proses milling pada mesin CNC vertical machining center dapat diamati selama proses machining. Pada proses pengerjaan machining pelat electrical steel lamination pada mesin CNC vertical machining center, digunakan piranti lunak CAM (computer aided manufacturing) untuk memudahkan dalam pembuatan program machining. Piranti CAM yang digunakan yaitu Mastercam ver. $\mathrm{X9}$. Pada gambar berikut ditunjukan desain inti besi untuk motor listrik kap. 800 Watt.

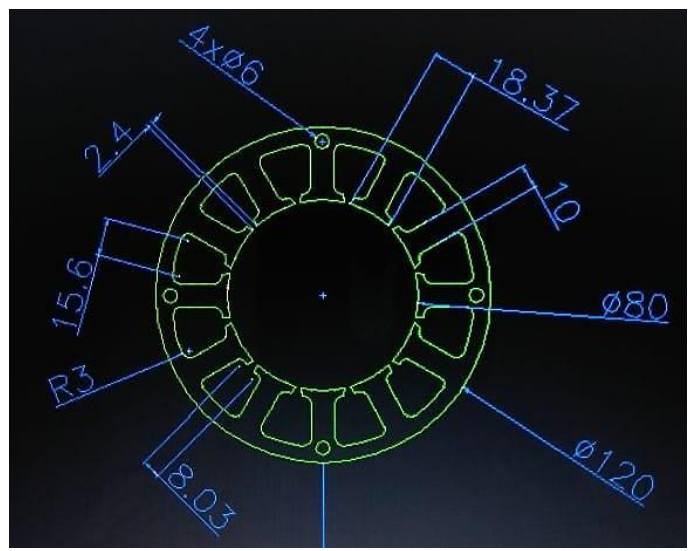

Gambar 2. Desain inti besi

Spesimen desain inti stator mempunyai diameter luar $120 \mathrm{~mm}$ (4.72 inci), diameter dalam $80 \mathrm{~mm}$ (3.15 inci), 12 slot, terdiri atas 185 lembar laminasi dengan ketebalan pelat lembaran masing-masing $0.27 \mathrm{~mm}$ (0.0106 inci) yang ditumpuk tanpa insulasi tambahan antara pelat satu dan lainnya dan digabungkan dengan proses weld stacking menggunakan mesin las GTAW. Pemilihan desain inti stator pada gambar diatas sebagai eksperimen dilatar belakangi oleh desain tersebut merupakan desain inti stator untuk motor BLDC (brushless direct current) 800 Watt, 48 Volt, tipe in runner yang akan digunakan untuk penggerak sepeda motor listrik.

Langkah pertama dari eksperimen pembuatan inti besi motor listrik dengan menggunakan proses milling pada mesin CNC vertical machining center yaitu material pelat electrical steel lamination yang masih berbentuk gulungan pelat, dipotong sesuai cutting plan dengan menggunakan mesin pemotong pelat. Langkah berikutnya yaitu, pelat electrical steel lamination hasil pemotongan, disusun dengan ketebalan maksimum tumpukan pelat electrical steel lamination yaitu $10 \mathrm{~mm}$. Pada gambar 2 berikut ini, ditunjukan tumpukan pelat electrical steel lamination.

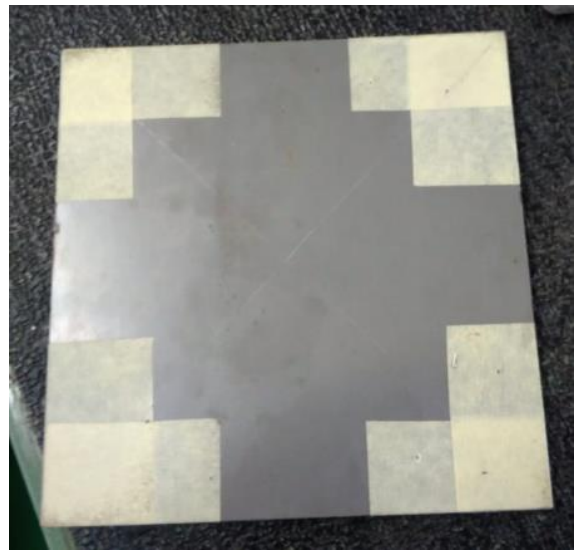

Gambar 3. Tumpukan pelat electrical steel lamination yang dipotong sesuai cutting plan 


\section{Perancangan Alat Bantu}

Alat bantu diperlukan untuk memegang/mencekam tumpukan pelat electrical steel lamination pada meja mesin CNC vertical machining center. Alat bantu pencekam (fixture) terbuat dari material mild steel S45C sehingga mudah untuk di-machining. Pada gambar berikut ditunjukan fixture untuk alat bantu pencekaman tumpukan pelat electrical steel lamination pada meja mesin CNC vertical machining center.

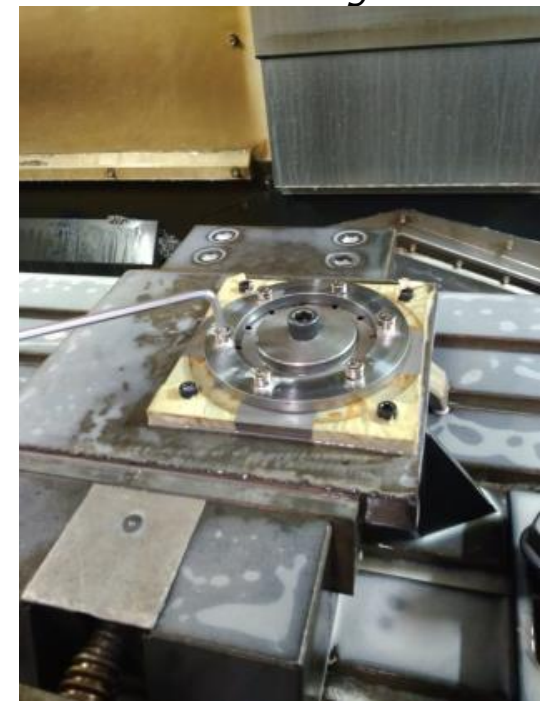

Gambar 4. Alat bantu pencekam pelat electrical steel lamination

\section{Perhitungan Parameter Pemesinan}

Parameter machining seperti kecepatan potong $(V c)$, feed rate $(F)$, dan depth of cut $(D o C)$ perlu dihitung untuk mendapatkan hasil pemesinan yang baik.

Kecepatan potong pada mesin milling dapat di formulakan sebagai berikut :

Speed $\frac{\text { rev }}{\min }=\frac{\operatorname{SFM}\left(\frac{f t}{\min }\right)}{\text { Circumference }(f t)}$

Formula untuk menghitung diameter cutting tools :

Speed $\frac{\text { rev }}{\min }=\frac{\operatorname{SFM}\left(\frac{f t}{\min }\right) \times 3.82}{\text { Dia }(\text { in })}$

Formula untuk menghitung feed rate pada mesin CNC milling, dituliskan sebagai berikut :

Feed $\frac{\text { in }}{\text { min }}=$ Speed $\frac{\text { Rev }}{\text { Min }} \times C L\left(\frac{\frac{i n}{\text { rev }}}{\text { flute }}\right) \times$ NumFlute

Dimana :

Speed : kecepatan spindle (rpm)

SFM (surface feet per minute) : kecepatan pemotongan material ( $\mathrm{ft} / \mathrm{min}$ )

Circumference : garis keliling pahat potong / cutting tools ( $f t$ )

Dia : diameter pahat (inch)

3.82 : konstanta mengubah lingkar cutting tools dalam satuan feet menjadi diameter dalam satuan inch.

Feed: gerakan linear pemakanan cutting tools pada benda kerja (inch per minute)

$C L$ : beban pemotongan untuk menghasilkan chip dalam satuan inches per rev (IPR)

NumFlutes : jumlah mata potong pada tools yang digunakan. 


\section{Proses Pemesinan Pada Mesin CNC Vertical Machining Center}

Langkah selanjutnya yaitu proses machining tumpukan pelat electrical steel lamination sesuai dengan desain yang telah dibuat pada mesin CNC Vertical Machining Center. Proses pemesinan yang dilakukan terdiri atas 4 OP (operation process). Proses pembuatan lubang (drilling) merupakan tahapan pertama dalam proses machining, hal ini bertujuan agar tumpukan pelat electrical steel lamination dapat dicekam pada alat bantu dan posisinya tidak bergeser pada saat dilakukan proses milling. Proses milling dilakukan dalam 2 tahapan yaitu proses roughing dan proses finishing. Proses milling roughing, digunakan untuk mengerjakan diameter luar dan diameter dalam, sedangkan proses milling finishing digunakan untuk membuat profil slot pada pelat electrical steel lamination sebagai tempat lilitan/kumparan. Pada gambar berikut ditunjukan proses machining dan hasil machining pada pelat electrical steel lamination.

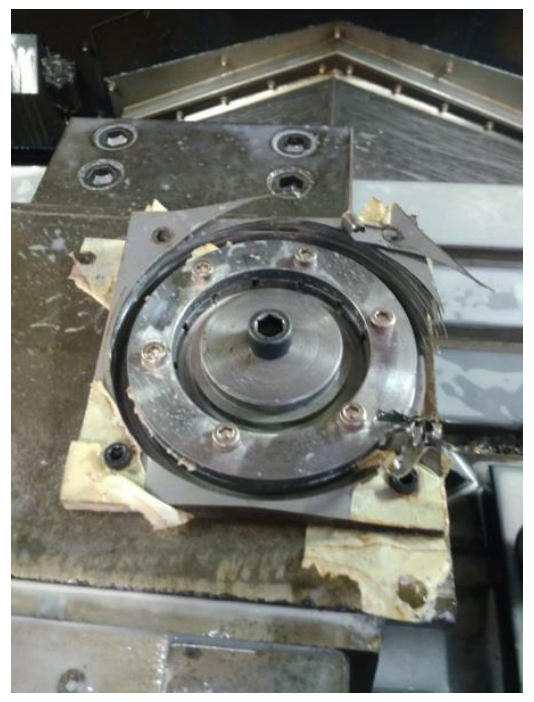

Gambar 5. Proses milling diameter luar dan diameter dalam

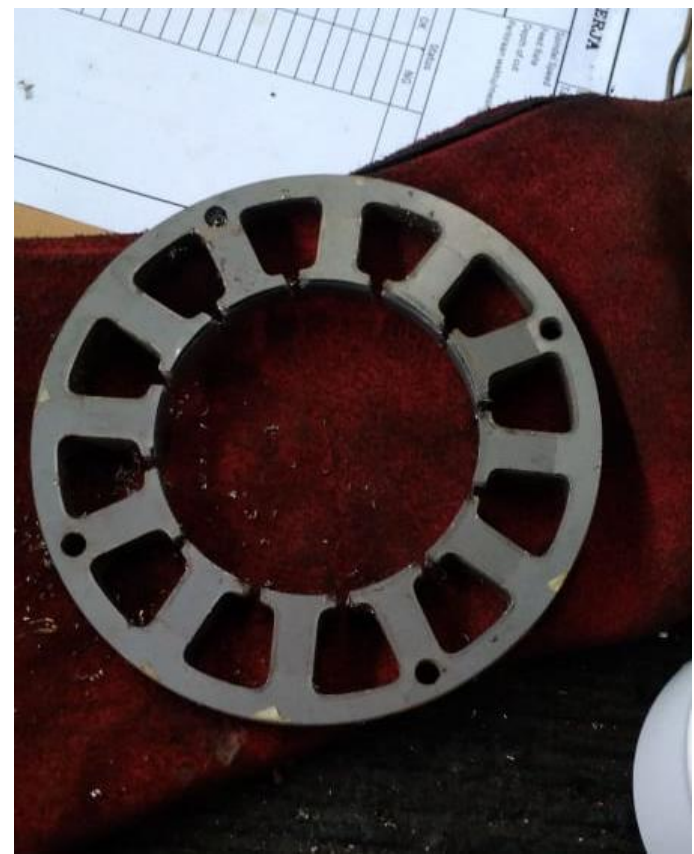

Gambar 6. Hasil machining pelat electrical steel lamination 
Pada gambar diatas, ditampilkan pelat inti stator motor listrik yang dibuat dengan menggunakan proses miling profil pada mesin CNC vertical machining center. Dibandingkan dengan spesifikasi pada desain awal, dimensi yang dihasilkan sesuai dengan program CAM yang telah dibuat, dan keseragaman hasil machining dikarenakan adanya alat bantu pencekam pelat electrical steel lamination pada saat proses milling profil.

\section{HASIL DAN PEMBAHASAN}

Dalam proses pembuatan program machining, diperlukan setting parameter machining yang sesuai. Pada proses milling terdapat 3 parameter yang mempengaruhi waktu proses milling, ketiga parameter tersebut yaitu diantaranya: kecepatan potong (cutting speed), feed rate (F) serta depth of cut (DoC).

Untuk itu dilakukan beberapa perhitungan menggunakan formula (1), (2) dan (3). Seperti ditunjukan pada tabel berikut.

Tabel 3. Proses operasi dan parameter pemesinan pembuatan lubang

\begin{tabular}{lllllll}
\hline OP & Proses & $\begin{array}{l}\text { Diameter } \\
\text { (inch) }\end{array}$ & $\begin{array}{l}\text { SFM } \\
(\mathrm{ft} / \mathrm{min})\end{array}$ & $\begin{array}{l}\text { IPR } \\
\text { (inch) }\end{array}$ & $\begin{array}{l}\text { Speed } \\
\text { (rev/min) })\end{array}$ & $\begin{array}{l}\text { Feed } \\
\text { (in/min) }\end{array}$ \\
\hline 1 & Drilling & 0.12 & 90 & 0.002 & 2865 & 5.73 \\
\hline 2 & Drilling & 0.28 & 90 & 0.002 & 1228 & 2.5 \\
\hline
\end{tabular}

Tabel 4. Proses operasi dan parameter pemesinan face milling

\begin{tabular}{|c|c|c|c|c|c|c|c|c|c|c|c|c|}
\hline $\begin{array}{l}\text { O } \\
P\end{array}$ & Proses & $\begin{array}{c}\text { Diam } \\
\text { eter } \\
\text { (inch) }\end{array}$ & $\begin{array}{c}\mathrm{SFM} \\
(\mathrm{ft} / \mathrm{min})\end{array}$ & $\begin{array}{c}\text { IPR } \\
\text { (inch) }\end{array}$ & $\begin{array}{l}\text { Numb } \\
\text { of } \\
\text { Flute }\end{array}$ & $\begin{array}{l}\text { Type } \\
\text { FEM }\end{array}$ & $\begin{array}{l}\text { Axial } \\
\text { DoC } \\
\text { (inch) }\end{array}$ & $\begin{array}{l}\text { Radial } \\
\text { DoC } \\
\text { (inch) }\end{array}$ & $\begin{array}{l}\text { MF } \\
\text { stee } \\
/\end{array}$ & $\begin{array}{l}\text { Speed } \\
\text { (rev/ } \\
\text { min) }\end{array}$ & $\begin{array}{c}\text { Feed } \\
\text { rate } \\
\text { (in } / \mathrm{min})\end{array}$ & $\begin{array}{c}P \\
(h p)\end{array}$ \\
\hline 3 & $\begin{array}{l}\text { Milling } \\
\text { roughin } \\
g\end{array}$ & 0.24 & 350 & $\begin{array}{c}0.00 \\
5\end{array}$ & 4 & $\begin{array}{l}\text { Solid } \\
\text { carbi } \\
\text { de }\end{array}$ & 0.12 & 0.168 & 1 & 5570 & 111 & 2.23 \\
\hline 4 & $\begin{array}{c}\text { Milling } \\
\text { finishing }\end{array}$ & $\begin{array}{c}0.12 \\
5\end{array}$ & 70 & $\begin{array}{c}0.00 \\
5\end{array}$ & 4 & HSS & $\begin{array}{c}0.062 \\
5\end{array}$ & 0.0875 & 1 & 2140 & 42.8 & 0.23 \\
\hline
\end{tabular}

Terdapat dua tipe gerak pemakanan pada proses milling yaitu climb (down) dan conventional (up) milling. Pada eksperimen ini, digunakan tipe gerak pemakanan climb milling dimana putaran cutting tools searah dengan pergerakan benda kerja yang dipotong. Pemilihan climb (down) milling, agar tekanan cutting tools pada benda kerja lebih kecil dibandingkan dengan tipe conventional (up) milling sehingga akan mengurangi panas yang timbul pada saat poses pemotongan. Dengan meminimalisir panas pada saat proses pemotongan dapat memperpanjang umur pakai cutting tools dan dan menghasilkan permukaan hasil pemotongan yang lebih baik. Hal ini sejalan dengan penelitian yang telah dilakukan oleh Chen et al., (2019) yang menyatakan bahwa gaya potong dan nilai kekasaran permukaan akan menurun, serta topografi permukaan akan menjadi lebih halus apabila kecepatan pemotongan dinaikan sementara feedrate atau depth of cut diturunkan. Pada gambar berikut ditampilkan gerak pemakanan climb (down). 


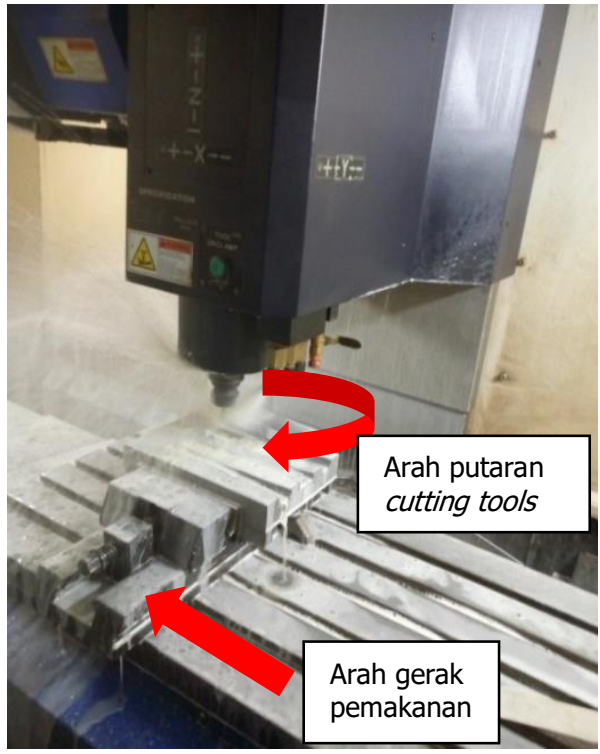

Gambar 7. Gerakan pemakanan climb down pada proses milling

Pada proses milling profil, cutting tools FEM digunakan untuk memotong keliling diameter bagian luar dan bagian dalam dari tumpukan pelat electrical steel lamination. Cutting tools FEM memotong dengan menggunakan mata potong yang terdapat pada sekeliling end mill dan bergerak mengikuti jalur profil (toolpath) sesuai program CAM. Pada pelaksanaan eksperimen, terdapat kendala seringnya FEM diameter 0.125 inch yang digunakan mengalami keausan, menurut Ozcan et al., (2017) menyatakan bahwa pada proses milling profil dan pocket, jalur gerakan cutting tools akan sering menemui sudut (corner) yang akan berpotensi mempercepat keausan cutting tools dan disebut dengan unsmooth toolpath. Akibat dari keausan cutting tools akan mempengaruhi hasil machining, dan akan berdampak pada timbulnya sisa-sisa pemotongan (burr ) pada permukaan benda kerja hasil pemotongan. Pada tepian pelat electrical steel lamination hasil milling finishing, terdapat burr sehingga mempengaruhi kehalusan permukaan hasil pemotongan. Menurut Niknam dan Songmene, (2014) menyatakan bahwa selain keausan cutting tools, faktor lain yang mempengaruhi timbulnya burr diantaranya yaitu kekerasan material benda kerja, feed per tooth dan cutting speed. Fenomena ini dikuatkan dengan penelitian yang telah dilakukan oleh Ko J.H., (2016), yang menyatakan keausan cutting tools akan berakibat pada perubahan tepian melintang pada permukaan FEM sehingga akan mempengaruhi kualitas permukaan dan stabilitas pemotongan cutting tools pada benda kerja. Untuk mengurangi laju keausan cutting tools maka digunakan cairan pendingin pada saat proses cutting. Cairan pendingin juga berfungsi untuk mengangkut geram (chip dari logam yang dipotong) menjauh dari area pemotongan. Dengan menggunakan cairan pendingin selama proses cutting akan menjaga stabilitas panas yang timbul pada cutting tools dan benda kerja, sehingga akan meningkatkan akurasi dimensi pada proses pemesinan presisi (Chris et al. 2020). Pada penelitian ini proses cutting berbeda dengan penelitian yang dilakukan oleh Davoudinejad et al., (2020), dimana pada penelitannya proses cutting dilakukan secara dry cut tanpa menggunakan media cairan pendingin. Pada saat proses machining, dibutuhkan penyesuaian setting parameter lainnya seperti kecepatan spinde/ maksimum atau spindle loading, kekakuan pencekaman benda kerja, kualitas dan kondisi cutting tools serta kemampuan mesin CNC vertical machining center itu sendiri. Pada penelitian ini, parameter cutting speed, feed rate dan depth of cut merupakan beberapa parameter pemesinan yang berpengaruh terhadap waktu proses pemesinan, hal ini sejalan dengan penelitian (Yudhyadi et al., 2016). 


\section{KESIMPULAN}

Berdasarkan hasil pengumpulan data, pada proses milling profil di mesin CNC vertical machining center untuk pembuatan inti stator motor listrik, maka dapat disimpulkan bahwa pembuatan inti stator yang terbuat dari lempengan pelat electrical steel lamination dapat dilakukan dengan metode alternatif menggunakan proses milling profil. Dibandingkan dengan proses stamping, proses pembuatan inti stator dengan proses milling profil pada mesin CNC vertical machining center mempunyai beberapa kelebihan yaitu perubahan desain produk dapat dilakukan dengan cepat tanpa harus mengubah dies dan punch-nya. Proses pembuatan pelat inti stator dengan menggunakan CNC vertical machining center lebih sesuai digunakan pada tahap prototyping sebelum dilakukan pembuatan inti stator ke tahap produksi massal. Perlu dilakukan penelitian lanjutan terhadap pengaruh parameter proses milling profil seperti penggunaan cutting tools yang berbeda dalam proses pemotongan pelat electrical steel lamination.

\section{UCAPAN TERIMA KASIH}

Ucapan terima kasih kepada BBLM/MIDC yang telah menfasilitasi kegiatan penelitian ini, Bapak Pujiyanto, Bapak Agus Suherman, Bapak Budy Nurdiansyah dan Bapak Widiyono dari BBLM/MIDC yang telah membantu pengumpulan data dan diskusi yang bermanfaat pada penelitian ini.

$\begin{array}{ll}\text { Nomenklatur } & \\ \text { Parameter proses milling }: \\ \text { SFM } & \text { surface feet per minute } \\ \text { IPM } & \text { inch per minute } \\ \text { IPR } & \text { Inch per revolution } \\ \text { Axial DoC } & \text { axial depth of cut } \\ \text { Radial DoC } & \text { radial depth of cut } \\ \text { Dia } & \text { diameter } \\ \text { MF } & \text { machining factor } \\ \text { OP } & \text { operation process }\end{array}$

\section{DAFTAR PUSTAKA}

Autodesk Inc., 2014. Autodesk CAM Fundamentals of CNC Machining, Desk Copy, ISBN 13:978-0-615-50059-1

Baumann, R. \& Rauscher, P., 2019. Fast Laser Cutting of Thin Metal. Procedia Manufacturing, 29, pp.369-374. doi.org/10.1016/j.promfg.2019.02.150.

Chen, Z. et al., 2019. Multiple Regression Prediction Model For Cutting Forces And Surface Roughness In Micro Milling Of TA2. Procedia CIRP, 89, pp.233-238. doi.org/10.1016/j.procir.2020.05.147.

Chris, M., Taylor, M. \& Crawforth, P., 2020. Resource Consumption And Process Quantity Lubricated Milling Of Tool Steel. Procedia Manufacturing, 43, pp.463-470. doi.org/10.1016/j.promfg.2020.02.187.

Davoudinejad, A. et al., 2020. Effect Of Progressive Tool Wear On Functional Performance Of Micro Milling Process Of Injection Molding. Procedia CIRP, 87, pp.159-163. doi.org/10.1016/j.procir.2020.02.031.

Gusev, V.G., Fomin, A.A. \& Sadrtdinov, A.R., 2017. Dynamics of Stock Removal in Profile Milling Process by Shaped Tool. Procedia Engineering, 206, pp.279-285. doi.org/10.1016/j.proeng.2017.10.474.

Harbintoro, S., Sutisna, A., Pujiyanto, Hidayat, S., Suherman, A., 2020. Pengembangan Proses Gerinda Silinder Permukaan Luar. Jurnal Rekayasa Mesin, Vol 11, Agustus, pp.277-286. doi.org/10.21776/ub.jrm.2020.011.02.14 
Hubert, M. et al., 2017. Rotary Cutting of Electrical Steel Laminations - A Contrast to Traditional Stamping. , ASTESJ, Vol. 2 No. 3, pp.1107-1113.

Jin, C., Guo, C. \& Gao, Y., 2017. Research on cutting vibration characteristics of face-milling involute gear. Defence Technology, Vol. 13, Issue 5, pp.380-384. doi.org/10.1016/j.dt.2017.05.012.

Ko, J.H., 2016. Milled Surface Affected By Damping Effect Of Cross Edge And Flank Profiles Of An End Mill. , Procedia CIRP 46, pp.500-503. doi: 10.1016/j.procir.2016.03.131

Niknam, S.A. \& Songmene, V., 2014. Analysis Of Friction And Burr Formation In Slot Milling. Procedia CIRP, 17, pp.755-759. doi.org/10.1016/j.procir.2014.02.032.

Ozcan, A. et al., 2017. Modelling Of Pocket Milling Operation Considering Cutting Forces And CNC Control Inputs. Procedia CIRP, 58, pp.239-244. doi.org/10.1016/j.procir.2017.03.187.

Pleta A., Niaki AF., Mears L., 2018. A Comparative Study On The Cutting Force Coefficient Identification Between Trochoidal And Slot Milling. Procedia Manufacturing, 26, pp.570579. doi.org/10.1016/j.promfg.2018.07.067.

Samantaraya D., Lakade S., Keche A., 2018. An Alternate Machining Method for Hardened Automotive Gears. Procedia Manufacturing, 20, pp.517-522. doi.org/10.1016/j.promfg.2018.02.077.

Silwal, B., Sergeant P., 2018. Thermally Induced Mechanical Stress in the Stator Windings of Electrical Machines. Energies 2018, 11, 2113; doi:10.3390/en11082113

Yudhyadi, I.G.N.K. et al., 2016. Optimasi Parameter Permesinan Terhadap Waktu Proses Pada Pemrograman CNC Milling Dengan Berbasis CAD / CAM. Dinamika Teknik Mesin, 6(1), pp.38-50.

Zhang, J. \& Spath, D., 2020. Progressive Die Cost Estimation Based on Lamination Design and and Production Scenario in the Electric Traction Motor Application. Procedia Manufacturing, 39(2019), pp.635-644. doi.org/10.1016/j.promfg.2020.01.438. 